\title{
ANALISIS LOGAM BERAT PADA PERAIRAN HUTAN MANGROVE DI KABUPATEN TANGERANG
}

\author{
Diana Rinawati ${ }^{1}$, Sofiatun ${ }^{1}$ \\ Jurusan Analis Kesehatan, Poltekkes Kemenkes Banten
}

\begin{abstract}
ABSTRAK
Hutan mangrove yang terdapat dipesisir kabupaten Tangerang umumnya dalam kondisi rusak. Pencemaran air laut oleh logam berat sudah terjadi di pesisir teluk Jakarta (Lestari, 2004). Hal ini menungkinkan pencemaran pesisir air laut terjadi di wilayah kabupaten Tangerang sesuai penelitian Annisa (2014) yang menyebutkan telah terjadi pencemaran di pesisir Cituis Kabupaten Tangerang. Penelitian ini merupakan penelitian deskriptif yang bertujuan mengetahui konsentrasi logam berat pada perairan hutan mangrove di kabupaten Tangerang. Pengambilan sampel air laut yang terdapat di hutan mangrove dibatasi pada hutan mangrove yang digenangi dan dialiri air laut. Sampel air laut di tiga lokasi yaitu Tanjung Pasir, Tanjung Kait dan Margamulya, sedangkan biota laut berupa plankton diperoleh di Tanjung Kait. Pemeriksaan logam berat pada air laut dilakukan di labortarium MIPA IPB Bogor. Konsentrasi logam berat pada hutan mangrove yang digenangi dan dialiri air laut pada titik sampling berada dibawah baku mutu yaitu Mercury $(\mathrm{Hg})$ dan Cadmium $(\mathrm{Cd})$. Sedangkan konentrasi Lead (Pb) dan Chromium (Cr) berada diatas baku mutu yaitu Lead 0,07 ppm dan Chromium adalah 0,09 ppm dam 0,54 ppm. Tingginya konsentrasi Lead $(\mathrm{Pb})$ dan Chromium $(\mathrm{Cr})$ diwilayah perairan hutan mangrove di Tanjung Kait dan Margamulya kabupaten Tangerang berasal dari bahan bakar kapal nelayan dan cat yang digunakan pada kapal nelayan dan kondisi hutan mnagrove yang rusak sehingga tidak optimal dalam menyerap logam berat. Untuk biota perairan hutan mangrove dalam penelitian ini diperoleh plankton yang diperoleh di Tanjung Kait dengan konsentrasi Lead ( $\mathrm{Hg}$ ), Cadmium $(\mathrm{Cd})$ dan Chromium $(\mathrm{Cr})$ berada diatas baku mutu. Hal ini sesuai dengan pernyataan dari buku Food adn Argicultur Organitation bahwa akumulasi logam berat mengkuti siklus rantai makanan, sehingga kedudukan yang paling tinggi dalam rantai makanan akan mengandung logam berat semakin tinggi.
\end{abstract}

Kata Kunci: mangrove, air laut, logam berat

Korespondensi: Diana Rinawati. E-mail: dianarinawati14rina@gmail.com

\section{PENDAHULUAN}

Indonesia merupakan negara kepulauan dimana sebagian besar wilayahnya merupakan lautan yang menjadikan Indonesia kaya akan hasil laut. Kondisi seperti ini menjadikan penduduk yang tinggal dipesisir pantai mempunyai mata pencaharian sebagai nelayan atau budidaya hasil laut, dimana kehidupan mereka sangat tergantung dari hasil laut.

Kualitas air laut secara tidak langsung mempengaruhi keberlangsungan hidup nelayan pesisir pantai, dengan kualitas air laut yang sudah tercemar dapat mengurangi biota laut 
dan keberagaman hasil laut. Pencemaran yang terjadi dilaut sudah diteliti oleh Lestari,dkk (2004), diwilayah perairan Ancol bahwa terdapat peningkatan kandungan logam berat diatas nilai ambang batas (NAB). Penelitian tersebut menyebutkan bahwa kematian massal ikan di pantai Ancol tidak disebabkan oleh pencemaran logam berat, melainkan ledakan fitoplankon beracun. Artinya ada faktor-faktor pemicu terjadinya ketidakseimbangan ekosistem laut, pencemaran salah satunya.

Air laut yang tercemar sangat merugikan masyarakat pesisir pantai dengan mata pencaharian sebagai nelayan, dimana kehidupan mereka sangat tergantung dengan jumlah hasil tangkapan. Pencemaran air laut oleh limbah dari kegiatan industri, sampah padat domestik dapat mengakibatkan memburuknya kualitas air laut. Hal ini menurut Belvia (2010) dapat mengancam kelestarian biota laut.

Hutan mangrove merupakan salah satu upaya penyelematan kualitas lingkungan di pesisir pantai. Dengan adanya pencemaran di perairan laut, keberadaan hutan mangrove dapat membantu meningkatkan kualitas perairan pesisir, karena hutan mangrove merupakan sumber kehidupan bagi biota laut dan kaya bahan organik serta bahan makan (plasma nuftah) (Sri Mekar, dkk,2011).

Kabupaten Tangerang dengan luas wilayah 959,61 km2 (95,961 ha) mempunyai garis pantai sepanjang $51,2 \mathrm{~km}$ kilometer merupakan wilayah penyanggah Ibu Kota DKI Jakarta yang sangat strategis, selain merupakan wilayah industri, kabupaten Tangerang mempunyai pantai yang cukup pajang. Wilayah pantai ini terdapat di kecamatan Teluknaga, Kosambi, Mauk, Kronjo, Kemeri dengan jumlah desa pesisir di kabupaten Tangerang sebanyak 23 desa (AMPL Kab.Tangerang, 2012). Adapun nama pantai diwilayah tersebut adalah Tanjungpasir, Tanjung burung, Tanjung kait, Pantai Mauk, Pantai Muara dan Kronjo. Luas hutan mangorve diwilayah pesisir kabupaten Tangerang 222,9 ha dengan kondisi yang mengalami kerusakan berat 145,4 ha, kondisi kerusakan sedang 61,7 ha dan kondisi baik 15,6 ha (Dinas Kelautan, 2014).

Kualitas air laut pesisir di kabupaten Tangerang di kecamatan Pakuhaji pesisir Cituis berdasarkan penelitian Annisa( 2014), sudah mengalami pencemaran logam berat baik pada musim hujan maupun pada musim kemarau dengan sebagian besar hutan mangrove mengalami kerusakan. Pencemaran ini didukung hasil penelitian Febi (2014) bahwa terdapat kandungan logam berat $\mathrm{Pb}$, $\mathrm{Cd}, \mathrm{Cu}$ pada bintang laut di perairan Kronjo dan Cituis Kabupaten Tangerang.

Berdasarkan latar belakang yang telah diuraikan, maka permasalahan dalam penelitian ini bagaimana pengaruh keberadaan hutan mangrove terhadap konsentrasi logam berat di pesisir kabupaten Tangerang.

Penelitian Analisis Logam Berat pada Air Hutan Mangrove mempunyai tujuan dan manfaat sebagai berikut:

Penelitian ini bertujuan:

a. Untuk mengetahui konsentrasi logam berat $(\mathrm{Hg}, \mathrm{Pb}, \mathrm{Cd}, \mathrm{Cr})$ pada air dan biota di hutan mangrove 
b. Untuk mengetahui jenis logam berat $(\mathrm{Hg}, \mathrm{Pb}, \mathrm{Cd}, \mathrm{Cr})$ yang paling tinggi konsentrasinya di perairan hutan mangrove

c. Untuk mengetahui gambaran wilayah perairan hutan mangrove di kabupaten Tangerang yang tercemar logam berat

\section{METODE PENELITIAN}

Penelitian ini merupakan jenis penelitian deskriptif untuk mengetahui gambaran kandungan logam berat pada perairan dilingkungan hutan mangrove di kabupaten Tangerang.

Populasi penelitian ini adalah pesisir pantai dengan hutan mangrove yang ada di kabupaten Tangerang. Sampel ditentukan pada wilayah hutan mangrove yang terdapat genangan/ aliran air laut. Sampel diambil pada dua kecamatan yaitu Teluk Naga di Tanjung Pasir, kecamatn Mauk di Tanjung Kait dan Margamulya, dengan biota plankton diambil di Tanjung Pasir kecamatan Teluk Naga.

Penelitian dilakukan dipesisir pantai kabupaten Tangerang pada bulan Oktober 2017. Kandungan logam berat $(\mathrm{Hg}, \mathrm{Pb}, \mathrm{Cr}$. Cd) pada perairan hutan mangrove di pesisir Kabupaten Tangerang. Data diperoleh dengan mengambil sampel air laut pada pesisir hutan mangrove di Kabupaten Tangerang. Data diperoleh di 3 titik pesisir pantai yang terdapat hutan mangrove dan digenangi atau dialiri air laut yaitu Tanjung Pasir, Tanjung Kait, Margamulya Kabupaten Tangerang

\section{PENGOLAHAN DAN ANALIS DATA}

Sampel air laut hutan mangrove yang telah diambil, dikirim dan diperiksa di laboratorium MIPA IPB Bogor. Analisis dilakukan terhadap hasil pemeriksaan kualitas air dan biota laut dengan parameter Logam Berat $(\mathrm{Hg}, \mathrm{Pb}, \mathrm{Cd}$, $\mathrm{Cr}$ ). Analisa data disajikan dalam bentuk tabel distribusi frekuensi dengan membandingkan pada baku mutu kepmen LH No.51 tahun 2004.

Adapun alat dan bahan yang diperlukan dalam pemeriksaan air dan biota laut diuraikan sebagai berikut (SNI)

a. Pemeriksaan Kualitas Air

- Peralatan

a) SSA;

b) lampu holow katoda $\mathrm{Pb}$;

c) gelas piala $250 \mathrm{~mL}$;

d) pipet ukur $1 \mathrm{~mL} ; 5 \mathrm{~mL} ; 10 \mathrm{~mL} ; 15 \mathrm{~mL}$ dan $20 \mathrm{~mL}$;

e) labu ukur $100 \mathrm{~mL}$;

f) corong gelas;

g) pemanas listrik;

h) kertas saring whatman 40, dengan ukuran pori $\theta 0.42 \mu \mathrm{m}$; dan

i) labu semprot .

- Bahan

a) air suling;

b) asam nitrat, $\mathrm{HNO} 3$;

c) larutan standar logam timbal, $\mathrm{Pb}$; dan

d) gas asetilen, $\mathrm{C} 2 \mathrm{H} 2$

\section{- Cara Kerja}

Bila contoh uji tidak dapat segera dianalisa, maka contoh uji diawetkan dengan penambahan $\mathrm{HNO} 3 \mathrm{p}$ sampai $\mathrm{pH}$ kurang 
dari 2 dengan waktu simpan maksimal 6 bulan.

- Persiapan pengujian

1. Persiapan contoh uji

a) Masukkan $100 \mathrm{~mL}$ contoh uji yang sudah dikocok sampai homogen kedalam gelas piala.

b) Tambahkan $5 \mathrm{~mL}$ asam nitrat.

c) Panaskan di pemanas listrik sampai larutan contoh uji hampir kering.

d) Ditambahkan $50 \mathrm{~mL}$ air suling, masukan ke dalam labu ukur $100 \mathrm{~mL}$ melalui kertas saring dan ditepatkan $100 \mathrm{~mL}$ dengan air suling.

2. Pembuatan larutan baku logam timbal, $\mathrm{Pb} 100$ mg/L

a) Pipet $10 \mathrm{~mL}$ larutan induk logam timbal, $\mathrm{Pb} 1000 \mathrm{mg} / \mathrm{L}$ ke dalam labu ukur $100 \mathrm{~mL}$.

b) Tepatkan dengan larutan pengencer sampai tanda tera.

3. Pembuatan larutan kerja logam timbal, $\mathrm{Pb}$

a) Pipet $0 \mathrm{~mL} ; 1 \mathrm{~mL} ; 5 \mathrm{~mL} ; 10 \mathrm{~mL} ; 15$ $\mathrm{mL}$ dan $20 \mathrm{~mL}$ larutan baku timbal, $\mathrm{Pb} \quad 10,0 \quad \mathrm{mg} / \mathrm{L}$ masing-masing ke dalam labu ukur $100 \mathrm{~mL}$.

b) Tambahkan larutan pengencer sampai tepat tanda tera sehingga diperoleh konsentrasi logam timbal $0,0 \mathrm{mg} / \mathrm{L}$; 1,0 mgLl; 5,0 mg/L; 10,0 mg/L; 15,0 $\mathrm{mg} / \mathrm{L}$ dan $20,0 \mathrm{mg} / \mathrm{L}$.

- Prosedur dan pembuatan kurva kalibrasi

a) Optimalkan alat SSA sesuai petunjuk penggunaan alat. b) Ukur masing-masing larutan kerja yang telah dibuat pada panjang gelombang $283,3 \mathrm{~nm}$.

c) Buat kurva kalibrasi untuk mendapatkan persamaan garis regresi.

d) Lanjutkan dengan pengukuran contoh uji yang sudah dipersiapkan.

- Perhitungan

Kosentrasi logam timbal, $\mathrm{Pb}$

$$
\mathrm{Pb}(\mathrm{mg} / \mathrm{L})=\mathrm{C} \times \mathrm{fp}
$$

dengan pengertian:

$\mathrm{C}$ adalah konsentrasi yang didapat hasil pengukuran (mg/L);

fp adalah faktor pengenceran.

4.7.2 Persen temu balik (\% Recovery, \% R)

$$
\% \mathrm{R}=\underline{\mathrm{A}-\mathrm{B} \times 100 \%}
$$

\section{$\mathrm{C}$}

dengan pengertian:

A adalah kadar contoh uji yang di spike;

B adalah kadar contoh uji yang tidak di spike; dan

C adalah kadar standar yang diperoleh (target value).

b. Pemeriksaan Biota

- Peralatan

- $\quad$ Alumunium foil

- Gelas beaker $25 \mathrm{ml} 100 \mathrm{ml}, 250$ $\mathrm{ml}$

- Blender/homogenizer

- Botol polypropylene

- Cawan porselen bertutup

- $\quad$ Corong plastik 
- Desikator

- Gelas ukur $25 \mathrm{ml}$ dan $50 \mathrm{ml}$

- Hot plate

- Labu takar $50 \mathrm{ml}$ (polypropylene) dan $1000 \mathrm{ml}$

- Labu takar $100 \mathrm{ml}$

- Mikrowave (khusus untuk destruksi contoh pengujian logam

- Mikropipet

- Oven

- $\quad$ Pipet tetes

- Pipet volumetrik $10 \mathrm{ml} 5 \mathrm{ml}$ dan $1 \mathrm{ml}$

- Pisau

- Refrigrerator/ freezer

- $\quad$ Sendok plastik

- Seperangkat alat Spectrofotometer Serapan Atom (AAS) dengan graphite furnace

- Timbangan analitik dengan ketelitian +/- 0,0001 g

- $\quad$ Tungku pengabuan (furnace)

- Wadah polystyrene

- catt: semua alat terlebih dahulu direndam dalam HNO3 air deionisasi (1:9) kemudian dibilas dengan air deionisasi

Pereaksi

- $\mathrm{HCl} 37 \%$

- $\mathrm{HCl} 6 \mathrm{M}$ (encerkan $500 \mathrm{ml} \mathrm{HCl}$ $37 \%$ dengan air deionisasi dan tepatkan hingga $1000 \mathrm{ml}$

- $\mathrm{HNO} 365 \%$

- $\mathrm{HNO3}$ 0,1M (encerkan $7 \mathrm{~m}$ HNO3 65\% dengan air deionisasi dan tepatkan hingga $1000 \mathrm{ml}$ )
- $\quad \mathrm{NH} 4 \mathrm{H} 2 \mathrm{PO} 4$ (larutan NH4H2PO4 $40 \mathrm{mg} / \mathrm{ml}$ sebagai matrik modifier; timbang 2,42 $\mathrm{g}$ NH4H2PO4 larutkan dengan air deionisasi didalam gelas beaker setelah larut dengan sempurna pindahkan kedalam labu takar 50 ml dan tepatkan sampai garis batas)

- larutan standar timbah $(\mathrm{Pb})$ dan kadmium $(\mathrm{Cd})$

$\checkmark$ larutan standar primer 1000 $\mathrm{mg} / \mathrm{l}$

$\checkmark$ larutan standar sekunder pertama : $10 \mathrm{mg} / \mathrm{l}$

Pipet $1 \mathrm{ml}$ larutan standar primer $1000 \mathrm{mg} / \mathrm{l}$ masukkan kedalam labu takar $100 \mathrm{ml}$ dan encerkan dengan larutan HNO3 0,1 M. Larutan standar ini dapat disimpan selama 1 bulan di dalam botol polypropylene

$\checkmark$ Larutan standar sekunder kedua: $1 \mathrm{mg} / \mathrm{l}$

Pipet $5 \mathrm{ml}$ dari larutan sekunder pertama masukkan kedalam labu takar $50 \mathrm{ml}$ dan encerkan dengan larutan HNO3 0,1 M. Larutan standar ini dapat disimpan selama 1 bulan di dalam botol polypropylene

Larutan standar sekunder ketiga: $1 \mathrm{mg} / \mathrm{l}$

Pipet $5 \mathrm{ml}$ dari larutan sekunder kedua masukkan 
kedalam labu takar $50 \mathrm{ml}$ dan encerkan dengan larutan HNO3 0,1 M. Larutan standar ini dapat disimpan selama 1 minggu di dalam botol polypropylene

Larutan standar kerja dibuat dari larutan standar sekunder ke-tiga yang konsentrasinya disesuaikan dengan daerah kerja alat AAS yang digunakan untuk logam $\mathrm{Pb}$ umumnya pada kisaran konsentrasi $1 \mathrm{ug} / \mathrm{l}$ - $20 \mathrm{ug} / \mathrm{l}$ dan untuk logam $\mathrm{Cd}$ pada kisaran konsentrasi 1 ug/l 10ug/l, larutan standar kerja ini harus dibuat ketika akan melakukan analisa

- Prosedur

\section{Pengabuan Kering (dry ashing)}

- Timbang produk basah sebanyak 5 gram atau produk kering sebanyak 0,5 g dalam cawan porselen dan catat beratnya (W)

- Buat kontrol posisitf $\mathrm{Pb}$ dan $\mathrm{Cd}$

- Uapkan spiked di atas hot plate pada suhu 100 derajat celcius sampai kering

- Masukkan contoh dan spiked kedalam tungku pengabuan dan tutup separuh permukaannya. Naikkan suhu tungku pengabuan secara bertahap 100 derajat celcius setiap 30 menit sampai mencapai 450 derajat celcius dan pertahankan selama 18 jam

- Keluarkan contoh dan spiked dari tungku pengabuan dan dinginkan pada suhu kamar. Setelah dingin tambahakan 1 $\mathrm{ml}$ HNO3 65\%, goyangkan secara hati-hati sehingga semua abu terlarut dalam asam dan selanjtunya uapkan diatas hot plate pada suhu 100 derajat celcius sampai kering

- Setelah kering masukkan kembali contoh dan spiked kedalam tungku pengabuan naikkan suhu secara bertahap 100 derajat celcius setiap 30 menit sampai 450 derajat celcius dan pertahankan selama 3 jam

- Setelah abu terbentuk sempurna berwarna putih, dinginkan conoth dan spiked pada suhu ruang. Tambahkan $5 \mathrm{ml} \mathrm{HCl} \mathrm{6M}$ kedalam masingmasing contoh dan spiked goyangkan secara hati-hati sehingga abu larut dalam asam. Uapkan diatas hot plate pada suhu 100 derajat celcius sampai kering.

- Tambahkan 10 ml HNO3 0,1 M dan dinginkan pada suhu 
ruang selama 1 jam, pindahkan larutan kedalam labu takar polypropylene $50 \mathrm{ml}$ dan tambahkan larutan matrik modifier, tepatkan sampai tanda batas dengan menggunakan HNO3 0,1M

\section{Distruksi basah menggunakan} microwave

- Timbang contoh basah sebanyak $2 \mathrm{~g}$ atau conoth kering sebanyak $0,2 \mathrm{~g}-0,5 \mathrm{~g}$ ke dalam tabung sampel (vessel) kemudian dicatat beratnya (W)

- Untuk kontrol positif (spiked 0,1 $\mathrm{mg} / \mathrm{kg}), \quad$ tambahkan masing-masing 0,2 $\mathrm{ml}$ larutan standar $\mathrm{Pb}$ dan $\mathrm{Cd} 1 \mathrm{mg} / \mathrm{l}$ atau larutan standar $\mathrm{Pb}$ dan $\mathrm{Cd} 200$ ug/l sebanyak $1 \mathrm{ml}$ ke dalam contoh kemudaian di vortex

- Tambahkan secara berurutan 5 $\mathrm{ml}$ - 10 ml- hNO3 65\% dan 2 $\mathrm{ml} \mathrm{H} 2 \mathrm{O} 2$

- Lakukan destruksi dengan mengatur microwave (sesuaikan dengan microwave yang digunakan)

- Pindahkan hasil destruksi ke labu takar $50 \mathrm{ml}$ dan tambahkan larutan matrik modifier, tepatkan sampai tanda batas dengan air deionisasi

\section{Tambahkan kurva kalibrasi dan} contoh pada AAS

- Siapkan larutan standar kerja $\mathrm{Pb}$ dan $\mathrm{Cd}$ masing-masing minimal 5 (lima) titik konsnetrasi

- Baca larutan standar kerja, conoth dan sipked pada alat spektrofotometer serapan atom graphite furnace pada panjang gelombang 283,3 nm untuk $\mathrm{Pb}$ dan 228,8 nm untuk Cd

\section{Perhitungan}

Konsentrasi $\mathrm{Pb}$ atau $\mathrm{Cd} u g / \mathrm{g}=$ (D-E) x Fp x V

W

\section{Keterangan:}

D adalah konsentrasi contoh ug/l dari hasil pembacaan AAS

E adalah konsentrasi blanko contoh ug/l dari hasil pembacaan AAS

Fp adalah faktor pengenceran V adalah volume akhir larutan contoh yang disiapkan (ml), harus diubah kedalam satuan liter W adalah berat contoh $(\mathrm{g})$

\section{HASIL DAN PEMBAHASAN}

Penelitian mengenai analisis logam berat pada hutan mangrove di kabupaten Tangerang

diperoleh hasil sebagai berikut:

- Hutan mangrove dari hasil survey pendahuluan banyak ditemukan diwilayah kecamatan Mauk dan Teluknaga yang memungkinkan untuk diambil sampel air laut. 
- Kondisi hutan mangrove dari hasil survey awal dalam kondisi rusak.

- Jenis hutan mangrove yang banyak tumbuh di wilayah pesisir kabupaten Tangerang dengan jenis api-api (avicennia).

- Sebagain besar pesisir yang ditemukan hutan mangrove tidak digenangi air laut, sehingga pengambilan sampel air laut tidak dilakukan

- Pengambilan sampel air laut pada hutan mangrove dilakukan pada satu titik di 3 (tiga ) lokasi yang representatif yaitu di desa Margamulya, Tanjung Pasir dan Tanjung Kait.

- Pemeriksaan kualitas air laut hutan mangrove di dilakukan di laboratorium MIPA IPB Bogor dengan methode APHA dan AOAC, alat yang digunakan AAS (Atomatic Absorption Spectrocopy).

Methode APHA digunakan untuk kualitas air laut sedangkan methode AOAC digunakan untuk plankton (biota) air laut. Metode APAH (American Public Health association) adalah standart method yang digunakan untuk melakukan pemeriksaan Air dan Air Limbah, methode AOAC (Association of Official Analytical Chemist) adalah methode kimia analisis yang didisain untuk meningkatkan kepercayaan diri dari hasil analisis kimia dan biologi.

- Sampel Biota hanya di peroleh di Tanjung Pasir, karena wilayah lain tidak ditemukan biota pada saat melakukan sampling.
Hasil Pemeriksaan Kualitas Air Laut Hutan Mangrove di Tanjung Pasir

\begin{tabular}{lccc}
\hline No & Parameter & $\begin{array}{c}\text { Hasil } \\
(\mathrm{mg} / \mathrm{l})\end{array}$ & $\begin{array}{c}\mathrm{BM} \\
(\mathrm{mg} / \mathrm{l})\end{array}$ \\
\hline 1. & Mercury $(\mathrm{Hg})$ & $<0.0001$ & 0.002 \\
2. & Lead $(\mathrm{Pb})$ & $<0.02$ & 0.005 \\
3. & Cadmium $(\mathrm{Cd})$ & $<0.005$ & 0.002 \\
4. & Chromium $(\mathrm{Cr})$ & 0.09 & 0.002
\end{tabular}

Ket: BM (Baku Mutu ) Kepmen KLH, 2005

Hasil pemeriksaan sampel air laut hutan mangrove di Tanjung Pasir diperoleh bahwa konsantrasi logam berat $75 \%$ berada dibawah baku Mutu (BM) dan 25\% berada diatas baku mutu (BM). Kandungan Mercury pada air hutan mangrove di Tanjung Pasir sebesar < 0,0001 mg/l berada di bawah Baku Mutu. Kandungan Lead sebesar $<0,02 \mathrm{mg} / \mathrm{l}$ dibawah baku mutu, kandungan Cadmium sebesar < 0,005 mg/l berada dibawah baku mutu dan kandungan Chromium sebesar $0,09 \mathrm{mg} / \mathrm{l}$ berada di atas baku mutu.

Hasil Pemeriksaan Kualitas Air Laut Hutan Mangrove di Tanjung Kait

\begin{tabular}{cccc}
\hline No & Parameter & $\begin{array}{c}\text { Hasil } \\
(\mathrm{mg} / \mathrm{l})\end{array}$ & $\begin{array}{c}\mathrm{BM} \\
(\mathrm{mg} / \mathrm{l})\end{array}$ \\
\hline 1. & Mercury $(\mathrm{Hg})$ & $<0.0001$ & 0.002 \\
2. & Lead $(\mathrm{Pb})$ & 0.07 & 0.005 \\
3. & Cadmium $(\mathrm{Cd})$ & $<0.005$ & 0.002 \\
4. & Chromium $(\mathrm{Cr})$ & 0.14 & 0.002
\end{tabular}

Ket: BM (Baku Mutu ) Kepmen KLH, 2005

Hasil pemeriksaan kualiatas air laut hutan mangrove di Tanjung Kait, konsentrasi logam berat $50 \%$ berada diatas baku mutu dan $50 \%$ berada dibawah baku mutu. Konsentrasi 
Mercury sebesar $<0,0001 \mathrm{mg} / \mathrm{l}$ berada dibawah baku mutu, konsentrasi Leada $0,07 \mathrm{mg} / \mathrm{l}$ berada diatas bakumutu, konsentrasi Cadmium sebesar $<0,005 \mathrm{mg} / \mathrm{l}$ berada dibawah baku mutu dan Ckromium (Cr) 0,14 mg/l berada diatas baku mutu.

Hasil Pemeriksaan Kualitas Air Laut Hutan mangrove di Margamulya

\begin{tabular}{cccc}
\hline No & Parameter & $\begin{array}{c}\text { Hasil } \\
(\mathrm{mg} / \mathrm{l})\end{array}$ & $\begin{array}{c}\mathrm{BM} \\
(\mathrm{mg} / \mathrm{l})\end{array}$ \\
\hline 1. & Mercury $(\mathrm{Hg})$ & $<0.0001$ & 0.002 \\
2. & Lead $(\mathrm{Pb})$ & 0.07 & 0.005 \\
3. & Cadmium $(\mathrm{Cd})$ & $<0.003$ & 0.002 \\
4. & Chromium $(\mathrm{Cr})$ & 0.54 & 0.002 \\
\hline
\end{tabular}

Ket: BM (Baku Mutu ) Kepmen KLH, 2004

Konsentrasi logam berat pada hasil pemeriksaan kualitas air laut hutan mangrove di Margamulya diperoleh konsentrasi logam berat $50 \%$ berada di bawah baku mutu, $50 \%$ berada diatas baku mutu. Konsentrasi Mercury sebesar <0,0001 mg/l berada dibawah baku mutu, konsentrasi Lead sebesar $0,07 \mathrm{mg} / \mathrm{l}$ berada diatas baku mutu, konsentrasi Cadmium sebesar $<0,003 \mathrm{mg} / \mathrm{l}$ berada dibawah baku mutu dan konsentrasi Chromium sebesar $0,54 \mathrm{mg} / \mathrm{l}$ berada diatas baku mutu.

Hasil Pemeriksaan Biota Luat (plankton) di Tanjung Kait

\begin{tabular}{cccc}
\hline No & Parameter & $\begin{array}{c}\text { Hasil } \\
(\mathrm{mg} / \mathrm{l})\end{array}$ & $\begin{array}{c}\mathrm{BM} \\
(\mathrm{mg} / \mathrm{l})\end{array}$ \\
\hline 1. & Mercury $(\mathrm{Hg})$ & $<0.001$ & 0.005 \\
2. & Lead $(\mathrm{Pb})$ & $<0.6$ & 0.001 \\
3. & Cadmium $(\mathrm{Cd})$ & $<0.1$ & 0.008 \\
4. & Chromium $(\mathrm{Cr})$ & $<0.4$ & 0.001 \\
\hline
\end{tabular}

Ket: BM (Baku Mutu ) Kepmen KLH, 2004

Hasil pemeriksaan biota (plankton) pada air hutan mangrove di Tanjung Kait diperoleh konsentrasi logam berat $75 \%$ berada atas baku mutu. Konsentrasi Mercury dibawah baku mutu yaitu $<0,001 \mathrm{mg} / 1$, konsentrasi Lead $<0,6$ $\mathrm{mg} / \mathrm{l}$ berada diatas baku mutu, konsentrasi Cadmium sebesar $<0,1 \mathrm{mg} / \mathrm{l}$ diatas baku mutu dan konsentrasi Chromium sebesart $<0,4 \mathrm{mg}$ / It berada diatas baku mutu.

Penelitian Analisis Logam Berat pada air laut hutan Mangrove di kabupaten Tangerang diperoleh hasil yang bervariasi, dimana lokasi penelitian hanya dilakukan pada dua kecamatan yang memungkinkan untuk dapat diperoleh air laut yang berada dihutan mangrove. Hutan mangrove yang dijumpai dibeberapa tempat yang direkomedasikan untuk diambil sampel tidak ditemukan genangan atau aliran air laut, sehingga sampel diambil pada tiga (3) titik dua kecamatan yaitu Tanjung Pasir, Tanjung Kait dan Margamulya. Kondisi hutan mangrove diwilayah kabupaten Tangerang dalam buku status lingkungan hidup provinsi Banten (2013) sudah mengalami kerusakan, sehingga program penanaman hutan mangrove menjadi program yang sangat penting dalam konservasi pesisir pantai di wilayah kabupaten Tangerang.

Pencemaran logam berat pada air laut dapat mengakibatkan terakumulasi pada biota laut melalui proses rantai makanan ( Ridhowati, 2013), sesuai dengan penelitian Emawati,dkk (2015) bahwa di temukan Timbal $(\mathrm{Pb})$ pada kerang-kerangan yang diperoleh di Teluk 
Jakarta diatas baku mutu yaitu sebesar13,98 $\pm 1,924 \mu \mathrm{g} / \mathrm{g}$ pada kerang hijau dan $33,64 \pm 4,66 \mu \mathrm{g} / \mathrm{g}$ pada kerang bulu. Dimana air laut Jakarta di ketahui telah mengandung logam berat berdasarkan penelitian Lestari (2004) walaupun sebagian besar masih berada di bawah baku mutu.

Dalam penelitian ini diperoleh logam berat pada plankton yang berada di air laut hutan mangrove Tanjung Kait diatas baku mutu. Konsentrasi logam berat Lead $(\mathrm{Pb})$ dan Chromium ( $\mathrm{Cr}$ ) dari ketiga titik sampling berada diatas baku mutu, sedangkan Mercury dan Timbal $(\mathrm{Pb})$ konsentrasinya berada dibawah baku mutu. Tingginya kandungan Lead $(\mathrm{Pb})$ dan Chromium $(\mathrm{Cr})$ dalam air laut disebabkan oleh pencemar yang berasal dari zat pewarna, mobiliasai bahan bakar, cat dan pupuk tanaman yang terbawa aliran air. (menurut Widowati, dkk (2008)

Konsentrasi logam berat di lingkungan perairan hutan mangrove dapat terakumulasi dalam sistem rantai makanan. Dimana daun dan ranting hutan mangrove yang jatuh menjadi bahan makanan bagi mikroba dan meiofauna yang merupakan sumber makanan bagi, udang, cacing (konsumen tingkat satu). Konsumen tingkat satu menjadi makanan kosumen tingkat 2 seperti burung, ikan selanjutnya dimakan manusia.(www.fao. org) Hutan mangrove menurut Saddiqi dan Zaidi (1994) tidak menyerap logam berat pada perairan yang tercemar, karena tidak ada hubungan antara kandungan logam berat pada sedimen dan hutan mangrove. Artinya jika hutan mangrove dibudidayakan dengan baik tidak dapat menurunkan konsentrasi logam berat, konsentrasi akan terakumulasi pada sedimen hutan mangrove. Pendapat ini berbeda dengan Puriyanto (2013) yang menyebutkan bahwa akar hutan mangrove dapat menyerap logam berat pada air laut karena akar dari hutan mangrove terendam air pada air pasang. Menurut penelitian Heriyanto,dkk (2011) pada bagian akar dan batang hutan mangrove dapat menyerap $\mathrm{Cu}$ dengan baik, bagian daun dan batang hutan mangrove dapat menyerap $\mathrm{Hg}$ dan $\mathrm{Pb}$ dengan baik. Keberadaan hutan mangrove sangat berpengaruh dalam menyerap logam berat yang mengkontaminasi air laut yang terdapat di hutan mangrove.

Logam berat terdapat dialam dalam kondisi normal, artinya logam berat dibutuhkan oleh mahkluk hidup pada konsetrasi tertentu. Konsentrasi logam berat yang melebihi baku mutu memberikan arti bahwa telah terjadinya pencemaran pada lingkungan. Logam berat dapat terakumulasi di alam jika proses self purifikasi tidak dapat berjalan dengan sempurna. Alam mempunyai kemampuan untuk melakukan pembersihan sendiri terhadap kontaminan. Akan tetapi jika kontiman lebih banyak dan terjadi terus menerus, maka kontaminan akan terakumulasi dialam pada kondisi tertentu dan membahayakan makhluk hidup.

Hutan mangrove yang terdapat di pesisir kabupaten Tangerang sebagian sebasar ditumbuhi jenis api-api, dengan permukaan tanah kering tidak terdapat genangan air laut. Konsentrasi logam berat pada air laut hutan mangrove pada titik sampling diketahui berada dibawah baku mutu, Lead $(\mathrm{Pb})$ dan Cromium 
(Cr) berada di diatas baku mutu. Tingginya konsentrasi Lead $(\mathrm{Pb})$ dan Chromium $(\mathrm{Cr})$ diwilayah hutan mangrove di Tanjung Kait dan Margamulya kabupaten Tangerang diindikasikan berasal dari bahan bakar kapal nelayan dan cat yang digunakan kapal nelayan, serta kondisi hutan mangrove yang rusak atau tidak sebaik hutan mangrove di Tanjung Pasir.

Untuk menghindari terjadinya rekontaminasi terhadap logam berat pada biota air laut hutan mangrove terutama pada ikan, udang yang dikonsumsi manusia, hal yang dapat dilakukan dengan mengolah sumber makanan tersebut dengan sabaik-baiknya. Untuk mencegah terjadinya akumulasi logam berat pada sedimen hutan mangrove akan sulit, jika air laut masih dijadikan tempat pembuangan limbah terutama logam berat. Logam berat merupakan logam yang membahayakan lingkungan dalam jangka panjang, secara alamiah logam berat berasal letusan gunung berapi, proses pelapukan bebatuan, sedangkan hasil aktifitas manusia berasal dari pembakaran hutan dan pembuangan limbah industri dan domestik. (Sembel, dkk, 2015)

\section{KESIMPULAN}

Hutan Mangrove merupakan salah satu ekosistem yang mempunyai banyak manfaat bagi manusia dan mahluk hidup lainnya. Hutan mangrove yang ada di kecamatan Mauk Kabupaten Tangerang merupakan lokasi penelitian dengan sebagian besar kondisi hutan mengalami kerusakan.

Hutan Mangrove di Tanjung Pasir kondisinya lebih baik dibanding Tanjung Kiat dan Marga
Mulya, akan tetapi konsentrasi logam berat $(\mathrm{Hg}, \mathrm{Cd}, \mathrm{Pb}, \mathrm{Cr})$ pada wilayah ini masih ditemukan walaupun berada dibawah baku mutu. Sedangkan di Tanjung Kait dan Marga Mulya konsentrasi logam berat Cadmium dan Chromium berada diatas baku mutu, konsentrasi Mercury dan Timbal berada dibawah baku mutu. Hal ini dapat menggambarkan bahwa keberadaan dan kondisi hutan mangrove di kecamatan Mauk yang tidak sebaik kondisi hutan mangrove di Tanjung Pasir mempengaruhi konsenstrasi logam berat terutama Lead $(\mathrm{Pb})$ dan Cromium

\section{SARAN}

Dari hasil penelitian dapat disarankan beberapa hal sebagai berikut:

- Penelitian dilanjutkan pada hutan mangrove di satu wilayah dengan kondisi hutan mangrove tidak rusak dengan beberapa titik sampling.

- Pengambilan sampel biota hutan mangrove dilakukan terhadap kepiting, yang terdapat pada wilayah tersebut

- Instansi terkait diharapkan memberikan sosialisai tentang pencemaran yang terjadi di perairan hutan mangrove dan memberikan peringatan bagi perorangan atau industri yang membuang limbah ke laut

- Masyarakat diharapkan dalam mengkonsumsi ikan, kepiting atau udang yang berasal dari hutan mangrove untuk melakukan 
pengolahan sebaik mungkin guna mengurangi kontaminasi logam berat.

\section{DAFTAR PUSTAKA}

Kepmenkes RI, 2006, Kepmenkes RI Nomor 424/Menkes/SK/VI/2006. Pedoman Pengendalian Cacingan. Jakarta : Depkes RI

Yus Rusila Noor, dkk. 2006, Panduan pengenalan mangrove di Indonesia. Ditjen PHKA dan Wetland International

Kepmen KLH, 2004, Keputusan Menteri Negara Lingkungan Hidup No. 51 Tahun 2004 Tentang Baku Mutu Air Laut

Subowo, Mulyadi, S. Widodo, dan Asep Nugraha. 1999. Status dan Penyebaran $\mathrm{Pb}, \mathrm{Cd}$, dan Pestisida pada Lahan Sawah Intensifikasi di Pinggir Jalan Raya. Prosiding. Bidang Kimia dan Bioteknologi Tanah, Puslittanak, Bogor.

M.Ghufran,H,dkk, 2008, Budi Daya Perairan Buku Satu, penerbit PT. Citra Aditya Bakti, Bandung

Arief, Arifin,Ir, 2003, Hutan Mangrove, Fungsi dan Manfaat, Kanisius, Yogyakarta

Sugiyarto,dkk, 2010, Kimia Anoragnik Logam, Graha Ilmu, Yogyakarta

Prodjosantoso,prof, dkk, 20111, Kimia Lingkungan, Kanisius, Yogyakarta

Rudjana,T, 2011, Seri Buku Informasi dan Potensi Mangrove Taman Nasional Alas Purwo, Balai Taman Nasional Alas Purwo

Siburian,Robert, 2016, Konservasi Mangrove dan Kesejahteraan Masyarakat, Yayasan Pusaka Obor, Jl. Plaju Jakarta

Gilang, R,dkk, 2014, Produksi Serasah Mangrove di Pesisir Tangerang, Banten (Litterfall Production of Mangrove in Tangerang Coastal Area, Banten), Jurnal Ilmu Pertanian Indonesia Agustus 2014 Vol. 19 (2): 9197 ISSN 0853 - 4217

Ridhowati, Sherly, 2013, Mengenal Pencemaran Ragam Logam, Graha Ilmu, Yogyakarta, 55283
Sembel,T,Dantje, 2015, Toksikologi Lingkungan, CV.Andi Offset, IKAPI, Yogyakarta, 55281

Widowati, dkk, 2008, Efek Toksik Logam, CV.Andi Offset, IKAPI, Yogyakarta, 55281

Lestari, dkk, 2004, Dampak Pencemaran Logam Berat Terhadap Kualitas Air Laut dan Sumber Daya Perikanan ( Studi Kasus Kematian Ikan-Ikan di Teluk Jakarta) Juurnal Makara, Sains, Vol 8, No.2 Agustus 2004: 52-58

www.fao.org, 2017, Food and Argiculture Organitation of the United Nations, Mangrove Management

Purwiyanto, S. I. 2013. Daya serap akar dan daun mangrove terhadap logam tembaga $(\mathrm{Cu})$ di Tanjung Api-Api, Sumatera Selatan. Maspari Journal. 5(1): 1-5. dalam Jurnal Ilmiah Mahasiswa Kelautan dan Perikanan Unsyiah

Heriyanto,dkk, 2011, Penyerapan Polutan Logam Berat $(\mathrm{Hg}, \mathrm{Pb}$ dan $\mathrm{Cu})$ Oleh Jenis-Jenis Mangrove (Absorption of Heavy Metal Pollutants $(\mathrm{Hg}, \mathrm{Pb}$ and $\mathrm{Cu}$ ) by Mangrove Species)*) jurnal Penelitian Hutan dan Konservasi Alam, Vol. 8 No. 2 : 177-188, 2011

http://jalatph32.blogspot.co.id/2012/05/mangro ve.html, Siddiqi, NA. and Hussain, KZ. 1994. The Impact of Deer on Natural Regeneration in the Sunderbands Mangrove Forest of Bangladesh. Bangladesh Journal of Zoology 22 (2), 223-234.

Emawati,Emma,dkk, Analisis Timbal dalam Kerang Hijau, Kerang Bulu, dan Sedimen di Teluk Jakarta, Jurnal IJPST (Indonesian Journal of Pharmaceutical Science and Technology), Volume 2, Nomor 3, Oktober 2015

Buku Data Status Lingkungan Hidup Daerah Provinsi Banten Tahun 2013 